\title{
KEEFEKTIFAN MODEL PEMBELAJARAN BERBASIS BUDAYA (PBB) UNTUK MENINGKATKAN HASIL BELAJAR IPS ${ }^{3}$
}

\author{
Firosalia Kristin \\ firosalia.kristin@gmail.com \\ Pendidikan Guru Sekolah Dasar - FKIP - UKSW Salatiga
}

\begin{abstract}
ABSTRAK
Penelitian ini bertujuan untuk mengetahui keefektifan penggunaan model Pembelajaran Berbasis Budaya (PBB) terhadap hasil belajar IPS siswa kelas 4 SD Negeri 01 Tridarma Wirajaya, Lampung. Rancangan yang digunakan dalam penelitian ini adalah eksperimen kuasi. Subjek dalam penelitian ini adalah semua siswa kelas 4A dan 4B di SD Negeri 01 Tridarma Wirajaya Lampung Pengumpulan data menggunakan teknik wawancara, observasi, dan tes. Teknik analisis yang digunakan dalam penelitian ini menggunakan uji $t$ untuk sampel independen. Hasil penelitian menunjukkan bahwa model PBB efektif untuk meningkatkan hasil belajar IPS siswa kelas 4 SD Negeri 01 Tridarma Wirajaya, Lampung. Hasil analisis data bahwa nilai rata-rata pre test hasil belajar kelompok eksperimen sebelum diberi model PBB pada pembelajaran IPS sebesar 7,53, sedangkan nilai rata-rata post test hasil belajar IPS setelah diberi tindakan pembelajaran dengan model PBB sebesar 17,13. Nilai rata-rata pre test kelompok kontrol adalah sebesar 7,37, sedangkan nilai rata-rata post test sebesar 14,66. Data gain score untuk kelas eksperimen 9,60 dan kelas kontrol 7,27. Data hasil uji-t didapat $t_{\text {hitung }}>t_{\text {tabel }}$ yaitu 3,343 $>2,000$.
\end{abstract}

Kata kunci: model pembelajaran berbasis budaya, hasil belajar IPS

\section{PENDAHULUAN}

Perubahan masyarakat yang sedemikian cepat sebagai dampak kemajuan ilmu pengetahuan dan teknologi, menuntut lembaga pendidikan untuk bisa mengimbangi percepatan perubahan yang ada di dalam masyarakat. Demikian juga lembaga pendidikan di Sekolah Dasar, dalam upaya membekali siswa untuk dapat bermasyarakat dengan baik, perlu meng-up date bahan pembelajarannya sesuai dengan perkembangan dalam masyarakat.

Mata pelajaran Ilmu Pengetahuan Sosial (IPS) adalah salah satu mata pelajaran yang berusaha membekali wawasan dan keterampilan siswa Sekolah Dasar untuk mampu beradaptasi dan bermasyarakat serta menyesuaikan dengan perkembangan dalam era globalisasi. Melalui mata pelajaran IPS, siswa

\footnotetext{
${ }^{3}$ Pernah di seminarkan dalam kegiatan Seminar Nasional dan Gelar Produk Penelitian dan PPM dengan tema "Penelitian dan PPM untuk Mewujudkan Insan Unggul", di LPPM UNY, 20-21 April 2015.
} 
diarahkan, agar dapat menganalisis fenomena sosial di sekitarnya (Irawan Sadad Sadiman dan Shendy Amalia, 2008). Upaya mata pelajaran IPS untuk membimbing siswa agar menjadi warga negara Indonesia yang baik dan warga dunia yang efektif merupakan tantangan yang berat karena dinamika masyarakat terus berkembang dan era globalisasi selalu mengalami perubahan di setiap saat, maka mata pelajaran IPS perlu dirancang untuk membangun dan merefleksikan kemampuan siswa dalam kehidupan bermasyarakat yang selalu berkembang secara terus menerus.

Pelaksanaan kegiatan pembelajaran di Sekolah Dasar pada umumnya masih menekankan aspek pengetahuan (kognitif) dan kurang melibatkan siswa secara aktif dalam proses pembelajaran. Demikian juga dalam pembelajaran IPS, guru merasa sudah melaksanakan pembelajaran ketika menyampaikan materi pembelajaran, tetapi model pembelajarannya kurang melibatkan aktifitas siswa secara optimal sehingga bekal pengetahuan dan keterampilan untuk hidup bermasyarakat kurang memadai. Guru berasumsi bahwa IPS adalah pengetahuan yang bisa ditransformasikan secara utuh dari pikiran guru ke benak siswa, sehingga model pembelajaran yang menekankan transformasi aspek pengetahuan mendominasi dalam kegiatan pembelajarannya.

Peningkatan kualitas pembelajaran IPS, menuntut kreativitas guru dalam mengembangkan model pembelajaran yang mampu melibatkan siswa secara aktif dan kreatif dalam proses pembelajaran. Model pembelajaran berbasis budaya merupakan salah satu model pembelajaran yang bisa dikembangkan dalam pembelajaran IPS untuk menumbuhkan keterlibatan siswa secara aktif dalam kegiatan pembelajaran. Model pembelajaran berbasis budaya ini membawa budaya lokal yang selama ini tidak selalu mendapat tempat dalam kurikulum sekolah, termasuk pada proses pembelajaran beragam mata pelajaran di sekolah. Melalui pembelajaran berbasis budaya ini diharapkan lingkungan belajar akan berubah menjadi lingkungan yang menyenangkan baik bagi guru maupun siswa, yang memungkinkan guru dan siswa berpartisipasi aktif berdasarkan budaya yang sudah mereka kenal, sehingga dapat diperoleh hasil belajar yang optimal.

Fenomena yang terjadi di SD Negeri 01 Tridarma Wirajaya Lampung, model pembelajaran yang digunakan masih bersifat konvensional, guru yang lebih aktif dibandingkan siswanya belum mempergunakan model pembelajaran yang bervariasi. Contohnya seperti model cooperative learning, model contextual teaching learning maupun model pembelajaran berbasis budaya. Hal itu dikarenakan guru kurang memahami tentang model-model tersebut dan merasa rumit untuk menerapkannya.

Pembelajaran berbasis budaya merupakan strategi penciptaan lingkungan belajar dan perancangan pengalaman belajar yang mengintegrasikan budaya 
Keefektifan Model Pembelajaran Berbasis Budaya (PBB) untuk Meningkatkan Hasil Belajar IPS (Firosalia Kristin)

sebagai bagian dari proses pembelajaran. Dalam pembelajaran berbasis budaya, budaya menjadi sebuah media bagi siswa untuk mentrasformasikan hasil observasi mereka ke dalam bentuk dan prinsip yang kreatif tentang alam. Dengan demikian, melalui pembelajaran berbasis budaya, siswa bukan sekedar meniru atau menerima saja informasi yang disampaikan tetapi siswa menciptakan makna, pemahaman, dan arti dari informasi yang diperolehnya.

Pembelajaran berbasis budaya merupakan pembelajaran yang meingintegrasikan budaya dalam proses pembelajaran serta salah satu bentuknya adalah menekankan belajar dengan budaya. Belajar dengan budaya dapat menjadikan siswa tidak terasing dari budaya lokalnya serta meningkatkan apresiasi siswa terhadap budaya lokal. Pembelajaran berabasis budaya juga merupakan pembelajaran yang bersifat konstruktivistik (Alexon, 2010: 14).

Pembelajaran berbasis budaya merupakan strategi penciptaan lingkungan belajar dan perancangan pengalaman belajar yang mengintegrasikan budaya sebagai bagian dari proses pembelajaran (Sutarno, 2012). Pembelajaran berbasis budaya dilandaskan pada pengakuan terhadap budaya sebagai bagian yang fundamental bagi pendidikan, ekspresi dan komunikasi suatu gagasan, serta perkembangan pengetahuan. Lebih lanjut Sutarno (2012) menjelaskan bahwa pembelajaran berbasis budaya sangat bermanfaat bagi pemaknaan proses dan hasil belajar bagi peserta didik untuk mendapatkan pengalaman belajar yang kontekstual dan bahan apersepsi untuk memahami konsep ilmu pengetahuan dalam budaya lokal (etnis) yang dimiliki Di samping itu, model pengintegrasian budaya dalam pembelajaran dapat memperkaya budaya lokal (etnis) tersebut yang pada gilirannya juga dapat mengembangkan dan mengukuhkan budaya nasional yang merupakan puncak-puncak budaya lokal dan budaya etnis yang berkembang. Dalam pembelajaran berbasis budaya, diintegrasikan sebagai alat bagi proses belajar untuk memotivasi peserta didik dalam mengaplikasikan pengetahuan, bekerja secara kooperatif, dan mempersepsikan keterkaitan antara berbagai mata pelajaran.

Dalam pembelajaran berbasis budaya, budaya menjadi sebuah metode bagi siswa untuk mentransformasikan hasil observasi mereka ke dalam bentukbentuk dan prinsip-prinsip yang kreatif tentang alam. Dengan demikian, melalui pembelajaran berbasis budaya, siswa bukan sekadar meniru dan atau menerima saja informasi yang disampaikan, tetapi siswa menciptakan makna, pemahaman,dan arti dari informasi yang diperolehnya. Pengetahuan, bukan sekadar rangkuman naratif dari pengetahuan yang dimiliki orang lain, tetapi suatu koleksi (repertoire) yang dimiliki seseorang tentang pemikiran, perilaku, keterkaitan,prediksi dan perasaan, hasil transformasi dari beragam informasi yang diterimanya (Akto Gunawan, 2012: 1). 
Pembelajaran berbasis budaya merupakan salah satu cara yang dipersepsikan dapat (1) Menjadikan pembelajaran bermakna dan kontekstual yang sangat terkait dengan komunitas budaya, di mana suatu bidang ilmu dipelajari dan akan diterapkan nantinya, dan dengan komunitas budaya dari mana kita berasal. (2) Menjadikan pembelajaran menarik dan menyenangkan. Kondisi belajar yang memungkinkan terjadinya penciptaan makna secara kontekstual berdasarkan pada pengalaman awal sebagai seorang anggota suatu masyarakat budaya. Hal ini sejalan dengan pemikiran aliran konstruktivisme.

Berdasarkan pemikiran tersebut, peneliti tertarik untuk mencoba menerapkan model pembelajaran berbasis budaya yang diharapkan dapat memberikan masukan bagi guru dalam menggunakan model pembelajaran ketika mengajar di kelas. Selain itu, penelitian ini dilakukan karena belum diketahui apakah penggunaan model pembelajaran berbasis budaya dalam pembelajaran IPS siswa kelas IV SD Negeri 01 Tridarma Wirajaya, Lampung lebih efektif dibandingkan dengan pembelajaran IPS tanpa menggunakan model pembelajaran berbasis budaya.

Berdasarkan uraian diatas, maka rumusan masalah dalam penelitian ini adalah (1) Apakah penggunaan model Pembelajaran Berbasis Budaya (PBB) lebih efektif dibandingkan dengan model konvensional untuk meningkatkan hasil belajar IPS siswa kelas IV SD Negeri 01 Tridarma Wirajaya, Lampung?; (2) Bagaimana perkembangan antusiasme, keaktifan, tanggung jawab, kepercayaan diri dan diskusi sebelum dan sesudah pemberian perlakuan model PBB?

\section{METODE PENELITIAN}

Penelitian ini merupakan penelitian kuantitatif dengan menggunakan metode kuasi eksperimen (quasi experimental design). Metode ini digunakan untuk menguji coba suatu metode pembelajaran dengan sengaja membangkitkan timbulnya sesuatu kejadian, kemudian diteliti bagaimana akibatnya.

Desain penelitian yang digunakan adalah pre test and post test design. Di dalam desain ini, tes hasil belajar dilakukan 2 kali yaitu sebelum pelaksanaan eksperimen (pretest) dan sesudah pelaksanaan eksperimen (posttest). Pola pretest and post test design dapat digambarkan sebagai berikut: $\mathrm{O}_{1}$ dan $\mathrm{O}_{2}$ merupakan hasil belajar IPS sebelum dan sesudah perlakuan model Pembelajaran Berbasis Budaya (PBB) dan pembelajaran konvensional.

Tempat penelitian di SD Negeri 01 Tridarma Wirajaya Lampung. Alasan peneliti memilih SD Negeri 01 Tridarma Wirajaya sebagai tempat penelitian karena berdasarkan wawancara dengan kepala SD Negeri 01 Tridarma Wirajaya, sekolah tersebut jarang dijadikan tempat penelitian dan hasil belajar IPS masih rendah dibanding dengan mata pelajaran lain. Penelitian ini dilaksanakan pada 
Keefektifan Model Pembelajaran Berbasis Budaya (PBB) untuk Meningkatkan Hasil Belajar IPS (Firosalia Kristin)

semester 1 tahun ajaran 2012/2013. Treatment atau pemberian perlakuan pada masing-masing kelompok dilakukan oleh guru yang sudah direkrut dengan mengikuti jadwal pelajaran di masing-masing kelas yang bersangkutan. Populasi dalam penelitian ini SD Negeri 01 Tridarma Wirajaya, Lampung. Yang menjadi populasi dari penelitian ini adalah seluruh siswa di kelas 4A dan kelas 4B SD Negeri 01 Tridarma Wirajaya Lampung, dengan jumlah siswa 29 orang sebagai kelompok eksperimen dan 27 orang sebagai kelompok kontrol.

Data dalam penelitian ini menggunakan teknik Tes dan observasi. Teknik tes dalam penelitian ini digunakan untuk mengukur hasil belajar dari kelas yang dikenai treatment. Observasi dilakukan peneliti selama proses pembelajaran

Tabel 1. Kisis-kisi soal tes

\begin{tabular}{|l|l|c|}
\hline \multicolumn{1}{|c|}{ Materi } & \multicolumn{1}{c|}{ Indikator } & No Soal \\
\hline $\begin{array}{l}\text { Ciri-ciri dan manfaat } \\
\text { kenampakan alam }\end{array}$ & $\begin{array}{l}\text { Ciri-ciri kenampakan alam } \\
\text { Manfaat kenampakan alam }\end{array}$ & 1,2 \\
\hline $\begin{array}{l}\text { Ciri-ciri sosial dan budaya di } \\
\text { kabupaten/kota } \\
\text { provinsi tempat tinggalnya }\end{array}$ & Ciri-ciri sosial & 3,5 \\
\hline $\begin{array}{l}\text { Keanekaragaman sosial dan } \\
\text { budaya di daerah }\end{array}$ & $\begin{array}{l}\text { Menentukan keanekaragaman } \\
\text { sosial dan budaya }\end{array}$ & 7,8 \\
\hline $\begin{array}{l}\text { Jenis-jenis sumber daya alam } \\
\text { dan kaitannya dengan kegiatan } \\
\text { ekonomi }\end{array}$ & $\begin{array}{l}\text { Jenis-jenis SDA dan kaitannya } \\
\text { dengan kegiatan ekonomi }\end{array}$ & 10,11 \\
\hline Persebaran sumber daya alam & Persebaran Sumber Daya Alam & 6 \\
\hline $\begin{array}{l}\text { Manfaat sumber daya alam } \\
\text { yang ada di lingkungan } \\
\text { setempat }\end{array}$ & Manfaat SDA & 12 \\
\hline $\begin{array}{l}\text { Bentuk-bentuk kegiatan } \\
\text { ekonomi di lingkungan tempat }\end{array}$ & $\begin{array}{l}\text { Bentuk-bentuk kegiatan } \\
\text { ekonomi }\end{array}$ & $\begin{array}{l}\text { Kegiatan ekonomi dan } \\
\text { pemanfaatannya }\end{array}$ \\
\hline $\begin{array}{l}\text { Kegiatan ekonomi dan } \\
\text { pemanfaatannya di lingkungan } \\
\text { tempat tinggalnya }\end{array}$ & 13 \\
\hline
\end{tabular}

berlangsung untuk mengetahui proses penerapan model Pembelajaran Berbasis Budaya (PBB) pada siswa kelas IV SD Negeri 01 Tridarma Wirajaya Lampung. Dalam proses pengamatan ini, peneliti bertindak sebagai non participant observation, artinya dalam melakukan kegiatan observasi, peneliti tidak terlibat langsung dalam kegiatan pembelajaran, tetapi peneliti hanya berperan sebagai pengamat independen. Guru mengajar sebagaimana biasanya, sementara peneliti dan pengamat mencatat, menganalisis, dan menarik kesimpulan dari hasil pengamatan pada proses pembelajaran. 
Tes tertulis dalam bentuk soal essay yang digunakan untuk mengambil data belajar siswa diawali pre test dan diakhiri dengan post test perlakuan. Pre test dilakukan sebelum perlakuan dimulai dan sementara post test dilakukan setelah perlakuan dimulai pada kelompok eksperimen dan kelompok kontrol. Materi tes dikembangkan dari Standar Kompetensi dan Kompetensi Dasar materi IPS Kelas IV SD Semester 1 tahun pelajaran 2012/2013. Adapun kisi-kisi instrumen tes tertulis yang dimaksud isajikan melalui tabel berikut ini:

Untuk mengamati proses pembelajaran yang berlangsung dengan seksama serta memantau perkembangan siswa dari waktu ke waktu, maka menggunakan lembar instrumen observasi. Observasi yang dilakukan yaitu selama 6 kali pada masing-masing kelas, pada saat pembelajaran berlangsung. Peneliti akan membandingkan hasil observasi dari setiap pertemuan dan melihat peningkatannya. Adapun kisi-kisi intrumen observasi disajikan melalui tabel 2 berikut:

Tabel 2. Kisi-kisi Lembar Observasi

\begin{tabular}{|l|l|l|}
\hline No & \multicolumn{1}{|c|}{$\begin{array}{c}\text { Aspek yang } \\
\text { Dinilai }\end{array}$} & \multicolumn{1}{c|}{ Indikator } \\
\hline 1 & Antusiasme & $\begin{array}{l}\text { a. Siswa antusias mendengarkan penjelasan } \\
\text { dan instruksi guru. } \\
\text { b. Siswa antusias melaksanakan } \\
\text { pembelajaran di kelas. }\end{array}$ \\
\hline 2 & Keaktifan & $\begin{array}{l}\text { a. Siswa aktif bertanya. } \\
\text { b. Siswa aktif memberi sumbang saran } \\
\text { serta pendapat. }\end{array}$ \\
\hline 3 & Tanggung Jawab & $\begin{array}{l}\text { Siswa bertanggungjawab dalam } \\
\text { penyelesaian tugas. }\end{array}$ \\
\hline 4 & $\begin{array}{l}\text { Kepercayaan } \\
\text { Diri }\end{array}$ & $\begin{array}{l}\text { Siswa terlihat percaya diri dan bangga akan } \\
\text { hasil kerjanya. }\end{array}$ \\
\hline 5 & Diskusi & $\begin{array}{l}\text { Siswa melakukan diskusi dengan teman } \\
\text { kelompok }\end{array}$ \\
\hline
\end{tabular}

Berdasarkan lembar observasi kegiatan siswa dalam pembelajaran IPS, maka dapat ditentukan kriteria (tolak ukur) yang akan dijadikan patokan penilaian selanjutnya. Skor maksimal sebesar 15 dan skor minimal adalah 5, sehingga penilaian terdiri dari tiga kategori, "Baik", "Cukup", dan "Kurang", sesuai dengan pengelompokkan skor. Rentangan skor dibagi tiga sama besar (Suharsimi Arikunto, 2007: 271), yaitu:

1) Skor (1) Kurang : :5-8,6

2) Skor (2) Cukup : :8,7-12,3 
Keefektifan Model Pembelajaran Berbasis Budaya (PBB) untuk Meningkatkan Hasil Belajar IPS (Firosalia Kristin)

\section{3) Skor 3 (Baik) : :12,4-15}

Teknik analisis yang digunakan dalam penelitian ini adalah uji t untuk sampel independen (independent sample $t$ test). Analisis ini digunakan untuk mengetahui signifikansi perbedaan antara kelas kontrol dan kelas eksperimen sebelum dan sesudah perlakuan. Sebelum perlakuan (pre test) diharapkan kedua kelompok itu tidak berbeda secara signifikan. Bilamana perlakuan Pembalajaran Berbasis Budaya (PBB) bersifat efektif, maka kelompok eksperimen meningkat lebih dibanding kelompok kontrol yang tanpa perlakuan PBB, sehingga setelah perlakuan (post test) ditemukan perbedaan yang signifikan antar kedua kelompok. Teknik analisis yang digunakan dalam penelitian ini adalah uji $\mathrm{t}$ untuk sampel independen (independent sample t test) dengan menggunakan formulasi (Burhan Nurgiantoro dkk, 2004: 183) sebagai berikut:

$$
\mathrm{t}=\frac{\overline{X 1}-\overline{X 1}}{\sqrt{\frac{S^{2}}{N 1}+\frac{S^{2}}{N 2}}}
$$

Pengujian hipotesis dilakukan dengan cara sebagai berikut:

1) Distribusi pengujian menggunakan independen sampel t-test untuk mengetahui apakah ada perbedaan hasil belajar IPS yang signifikan antara kelas kontrol dengan kelas eksperimen.

2) Keputusan diambil dengan cara membandingkan nilai $t_{\text {hitung }}$ dengan $t_{\text {tabel }}$. Jika $\mathrm{t}_{\text {hitung }}<\mathrm{t}_{\text {tabel }}$, maka keputusan menerima $\mathrm{H}_{0}$. Sebaliknya, jika $\mathrm{t}_{\text {hitung }}>\mathrm{t}_{\text {tabel }}$ maka keputusan tidak menerima $\mathrm{H}_{0}$ dan menerima $\mathrm{H}_{\mathrm{a}}$.

3) Kesimpulan ditarik berdasarkan keputusan yang diambil. Jika keputusan menerima $\mathrm{H}_{0}$, kesimpulannya adalah tidak ada perbedaan hasil belajar yang signifikan antara kelas kontrol dan kelas eksperimen. Sebaliknya, jika keputusan menolak $\mathrm{H}_{0}$ dan menerima $\mathrm{H}_{\mathrm{a}}$, kesimpulannya terdapat perbedaan hasil belajar yang signifikan antara kelas kontrol dan kelas eksperimen.

Dalam penelitian ini untuk menjaga validitas eksperimen, peneliti berkoordinasi dengan guru terkait pembelajaran yang akan dilakukan. Peneliti menjelaskan maksud dari model PBB, langkah pembelajaran PBB, dan instrumen untuk mengukur hasil belajar.

\section{HASIL DAN PEMBAHASAN}

Uji hipotesis dilakukan dengan uji-t pada masing-masing kelompok data, baik kelas eksperimen maupun kelas kontrol. Hasil uji hipotesis dikatakan signifikan apabila $\mathrm{t}_{\text {hitung }}>$ dari $\mathrm{t}_{\text {tabel }}$ dengan $\mathrm{db}=(\mathrm{n}-1)$ pada taraf signifikansi $(\alpha)$ $=0,05$. Namun sebelum uji dilaksanakan, terlebih dahulu hitung normalitas dan homogenitas dan homogenitas data gain. Untuk mengetahui data tersebut nomal, 
maka dilakukan uji kolmogorov-smirnov dengan bantuan SPSS 16. Hasil uji normalitas menunjukan bahwa sig. pada kelas kontrol dan kelas eksperimen masing-masing adalah 0,086 dan 0,200 nilai signifikansi kedua kelas tersebut lebih dari 0,05, maka menunjukan bahwa data gain hasil belajar yang diperoleh dari kelas eksperimen dan kelas kontrol berdistribusi normal.

Setelah melakukan uji normalitas, maka dilanjutkan dengan uji homogenitas data gain kelas eksperimen dan kelas kontrol menggunakan uji Levenne's test. hasil uji homogenitas menunjukan angka sig. $=0,326$ oleh karena angka sig lebih dari 0,05, maka data Gain kelas kontrol dan kelas eksperimen bersifat homogen atau memiliki varian yang sama. Setelah melakukan uji prasarat, selanjutnya dilakukan uji hipotesis. Dikarenakan data gain menunjukan data yang normal dan homogen, maka ipengujian hipotesis menggunakan uji parapetrik tes yaitu uji indepedent simple t-test menggunakan SPSS 16.

Hasil analisis data indepedent simple t-test menggunakan SPSS 16 menunjukkan bahwa nilai rata-rata pretest hasil belajar kelas eksperimen sebelum diberi model PBB pada pembelajaran IPS adalah sebesar 7,53, sedangkan nilai rata-rata post test hasil belajar IPS setelah diberi model PBB adalah sebesar 17,13. Nilai rata-rata prtest kelas kontrol dengan model konvensional adalah 7,37, sedangkan nilai rata-rata post test adalah sebesar 14,66. Data gain untuk kelas eksperimen 9,60, dan kelas kontrol 7,27. Dari hasil uji-t didapat $\mathrm{t}_{\text {hitung }}>\mathrm{t}_{\text {tabel }}$ yaitu 3,343>2,000.

Dilihat dari besarnya rerata skor data pretest dan post test, maka dapat disimpulkan bahwa peningkatan rerata skor untuk kelas eksperimen lebih besar daripada peningkatan yang terjadi pada kelas kontrol. Hal ini berarti penggunaan model PBB lebih efektif dibandingkan model konvensional. Disamping itu model PBB dapat meningkatkan aktivitas belajar siswa pada lima aspek yaitu antusiasme, keaktifan, tanggung jawab, kepercayaan diri, dan diskusi, bahwa dari ke lima aspek tersebut dari pertemuan pertama sampai pertemuan ke enam mengalami kenaikan yang signifikan.

Penggunaan model konvensional juga dapat meningkatkan hasil belajar siswa, tetapi peningkatan yang terjadi tidak sebesar peningkatan yang terjadi pada kelas yang menggunakan model PBB. Model konvensional yang digunakan pada kelas kontrol berupa ceramah, tanya jawab, demonstrasi. Ceramah dan demonstrasi yang dilakukan oleh guru dapat membantu siswa memahami materi yang sedang berlangsung serta mengerjakan tugas yang diberikan oleh guru. Tugas yang diberikan bersifat individu, sehingga para siswa mengalami kesulitan untuk memecahkan masalah-masalah IPS sehingga mereka tidak dapat menyelesaikan tugas yang diberikan dengan cepat dan tepat. 
Keefektifan Model Pembelajaran Berbasis Budaya (PBB) untuk Meningkatkan Hasil Belajar IPS (Firosalia Kristin)

Proses pembelajaran merupakan suatu kegiatan dalam rangka melaksanakan kurikulum pada sekolah, agar dapat membantu siswa untuk mencapai tujuan pendidikan yang telah ditetapkan. Tujuan pendidikan pada hakikatnya ingin merubah perilaku, intelektual dan moral maupun sosial agar bisa mandiri dalam kehidupan masyarakat. Dalam mencapai tujuan pendidikan tersebut siswa berinteraksi dengan lingkungan belajar yang diatur guru melalui proses pembelajaran. Peran model pembelajaran dalam pembelajaran sebagai upaya untuk meningkatkan kualitas proses belajar mengajar dengan harapan mampu meningkatkan kualitas hasil belajar siswa.

Dalam penelitian ini siswa melakukan kegiatan pengamatan di luar kelas tentang kenampakan alam yang ada di sekitar sekolah dan tempat tinggal mereka. Melalui pengamatan tersebut siswa menemukan beberapa kenampakan alam seperti rawa, sungai, pantai, gunung. Hasil dari pengamatan tersebut memampukan siswa untuk mengkonstruk pengalaman belajarnya menjadi sebuah konsep pembelajaran baru yang berkaitan dengan budaya yang ada di lingkungan mereka, seperti masyarakat yang tinggal di daerah pantai rata-rata mata pencaharian mereka sebagai nelayan, pakaian yang digunakan rata-rata dari bahan yang tipis/katun karena cuaca panas (budaya yang berlaku di daerah tersebut). Hal ini sesuai dengan pendapat Paul Suparno (2012: 18) yang mengatakan bahwa konstruktivisme adalah suatu filsafat pengetahuan yang menekankan bahwa pengetahuan kita adalah konstruksi (bentukan) kita sendiri. Pengetahuan bukanlah suatu tiruan dari kenyataan (realitas) dan bukanlah gambaran dunia kenyataan yang ada.

Peranan guru dalam hal pendekatan konstruktivisme adalah membantu siswa mengembangkan pengertian baru. Hal ini juga dipertegas teori konstruksi sosial yang menekankan bahwa intelegensi manusia berasal dari masyarakat, lingkungan dan budayanya. Teori ini juga menegaskan bahwa perolehan kognitif individu terjadi pertama kali melalui interpersonal (interaksi dengan lingkungan sosial) dan intrapersonal (internalisasi yang terjadi pada diri sendiri).

Media sebagai alat bantu pembelajaran, berperan untuk menunjang penggunaan metode pembelajaran yang akan diterapkan oleh guru agar penyampaian bahan belajar bisa lebih efektif dan efisien. Seperti halnya dalam penelitian ini menggunakan budaya yang ada di lingkungan sekitar sekolah dan daerah tempat tinggal siswa sebagai media pembelajaran IPS melalui materi kenampakan alam dan sumber daya alam. Siswa dapat mengekspresikan hasil observasi yang telah dijelaskan di atas melalui karyanya, misalnya membuat poster tentang gunung yang asri, bercerita tentang manfaat sumber daya alam singkong di bidang ekonomi. 
Prose belajar tidak dapat dipisahkan dari aksi (aktivitas) dan interaksi, karena persepsi dan aktivitas berjalan seiring secara dialogis. Belajar merupakan proses penciptaan makna sebagai hasil pemikiran individu melalui interaksi dalam suatu konteks sosial. Dalam hal ini, tidak ada perwujudan dari suatu kenyataan yang dapat dianggap lebih baik atau benar. Sesuai dengan pendapat Vygotsky (Sri Utami Halman, 2012) bahwa beragam perwujudan dari kenyataan digunakan untuk beragam tujuan dalam konteks yang berbeda-beda. Pengetahuan tidak dapat dipisahkan dari aktivitas di mana pengetahuan itu dikonstruksikan dan di mana makna diciptakan, serta komunitas budaya di mana pengetahuan didesiminasikan dan diterapkan. Melalui aktivitas, interaksi sosial dan komunitas budaya tersebut penciptaan makna terjadi.

Nana Sujana (2007: 7) menyatakan bahwa peran model pembelajaran sebagai penunjang dalam penerapan metode pembelajaran, sehingga meningkatkan kualitas interaksi siswa dengan guru sesuai dengan karakteristik siswa dan bahan belajar yang akan disampaikannya.

Peningkatan atau pemahaman terjadi secara kolektif oleh siswa karena adanya kolaborasi, interaksi langsung atau face-to-face interaction, dan saling ketergantungan positif atau positive interdependence yang dibentuk oleh siswa selama proses pembelajaran. Hal ini sejalan dengan teori Kagan (1994), dan Johson and Johson (Howe \& Jones, 1993: 195) yang menyatakan dengan adanya usaha saling ketergantungan positif dan interaksi langsung, siswa dapat saling mengajarkan pengetahuan, menjelaskan cara pemecahan masalah, mendiskusikan materi yang sedang dipelajari, serta adanya rasa tanggung jawab terhadap kesuksesan kelompok. Siswa dengan kemampuan intelektual tinggi dapat berbagi ilmu kepada siswa dengan kemampuan intelektual rendah dalam memecahkan persoalan yang diberikan kepada mereka. Hal ini sejalan dengan konsep ZPD (Zona Perkembangan Proximal) yang dikemukakan oleh Vygotsky (Sri Utami Halman, 2012). Konsep ZPD menekankan bahwa tugas yang cukup sulit dikerjakan oleh anak itu sendiri, maka mereka memerlukan bantuan dari orangorang dewasa atau anak yang terampil. Ketika anak-anak mengalami pembelajaran atau contoh verbal, mereka mengorganisasikan informasi dalam struktur mental mereka sehingga pada akhirnya mereka dapat melaksanakan sendiri keterampilan atau tugasnya (Santrock, 2004: 247).

Mencermati penjelasan di atas, dapat disimpulkan bahwa pembelajaran IPS dengan model pembelajaran berbasis budaya lebih efektif dibandingkan dengan model konvensional. Pernyataan tersebut didukung dengan pendapat Ali Muhtadi (2008: 8-9) yang menyatakan bahwa guru dapat membantu siswa dengan cara memfokuskan perhatian, menentukan mana yang penting, sulit dan tidak jelas, memberitahu tujuan pengajaran yang akan diberikan, agar siswa dapat 
Keefektifan Model Pembelajaran Berbasis Budaya (PBB) untuk Meningkatkan Hasil Belajar IPS (Firosalia Kristin)

memfokuskan perhatiannya pada hal-hal penting bukan pada hal-hal yang tidak penting, membantu mengingat kembali informasi yang telah dipelajari sebelumnya, dan menggabungkan informasi baru dengan informasi dalam memori jangka panjang.

Berdasarkan pendapat di atas, bahwasanya pembelajaran berbasis budaya merupakan strategi penciptaan lingkungan belajar dan perancangan pengalaman belajar yang mengintegrasikan budaya sebagai bagian dari proses pembelajaran (Akto Gunawan, 2012). Dalam pembelajaran berbasis budaya, budaya diintegrasikan sebagai alat bagi proses belajar untuk memotivasi siswa dalam: (1) mengkonstruksikan pengetahuan, (2) bekerja secara kooperatif, dan (3) mempersepsikan keterkaitan antara berbagai bidang ilmu. Sebagai suatu strategi belajar, pembelajaran berbasis budaya mendorong terjadinya imaginative, metaforik, berpikir kreatif, dan juga sadar budaya. Salah satu mata pelajaran yang dapat diintegrasikan dengan Pembelajaran Berbasis Budaya (PBB) adalah pendidikan IPS.

Pendidikan IPS di tingkat sekolah pada dasarnya bertujuan untuk mempersiapkan para siswa sebagai warga negara yang menguasai pengetahuan (knowlwdge), keterampilan (skill), sikap dan nilai (attitudes and values) yang dapat digunakan sebagai kemampuan untuk memecahkan masalah pribadi atau masalah sosial serta kemampuan mengambil keputusan dan berpartisipasi dalam berbagai kegiatan masyarakat agar menjadi warga negara yang baik. Siswa belajar IPS harus memiliki kemampuan minimal yang terukur berdasarkan kreteria tertentu. Penguasaan sejumlah kemampuan hasil belajar siswa disebut dengan istilah kompetensi.

Kemampuan hasil belajar tersebut, dibutuhkan suatu kemampuan menguasai materi. Hasil belajar adalah pengguna/pemakaian keterampilanketerampilan kognitif atau strategi untuk meningkatkan suatu hasil yang diinginkan. Hasil belajar adalah kemampuan yang diperoleh siswa setelah melalui kegiatan belajar Mulyono Abdurrahman (2003: 37). Hasil belajar digunakan sebagai ukuran untuk mengetahui seberapa jauh seseorang menguasai bahan yang sudah diajarkan. Untuk mengaktualisasikan hasil belajar tersebut diperlukan serangkaian pengukuran menggunakan alat evaluasi yang baik dan memenuhi syarat. Pengukuran demikian dimungkinkan karena pengukuran merupakan kegiatan ilmiah yang dapat diterapkan pada berbagai bidang termasuk pendidikan.

Untuk menumbuhkan motivasi belajar siswa, sehingga diharapkan dapat meningkatkan partisipasi dalam belajar maka pembelajaran harus dirancang secara kreatif, yang memungkinkan terjadinya interaksi dan negosiasi untuk penciptaan arti dan konstruksi makna dalam diri siswa dan tenaga pengajar, 
sehingga dicapai pembelajaran yang bermakna. Perancangan pembelajaran yang kreatif dan bermakna menjadi penting karena meskipun pembelajaran merupakan proses yang universal, pada kenyataannya pembelajaran terjadi pada suatu komunitas budaya tertentu, demikian juga dengan hasil belajar akan diterapkan pada komunitas budaya tertentu pula. Dalam hal ini, pemanfaatan budaya lokal dalam pembelajaran merupakan salah satu bentuk perancangan pembelajaran yang kreatif untuk menghasilkan pembelajaran yang bermakna secara kontekstual.

Faktor-faktor yang mempengaruhi belajar siswa dijelaskan oleh Paulina Pannen (Saliman, 2007: 2) yang meliputi faktor kebebasan, tanggung jawab, pengambilan keputusan, pengarahan diri sendiri, psikologis, fisik, daya ingat, dan motivasi. Dari beberapa faktor tersebut motivasi belajar perlu mendapatkan perhatian secara khusus, karena motivasi belajar yang rendah tampaknya menjadi faktor penyebab utama terhadap rendahnya partisipasi siswa dalam belajar. Brooks \& Brooks (Saliman, 2007: 3) percaya bahwa pendekatan pembelajaran berbasis budaya dapat memberikan kesempatan kepada peserta didik untuk menciptakan makna dan mencapai pemahaman terpadu atas informasi keilmuan yang diperolehnya, serta penerapan informasi keilmuan tersebut dalam konteks permasalahan komunitas budayanya.

Teori kognitif lebih mengutamakan proses belajar daripada hasil belajar. Menurut teori ini, belajar tidak sekedar melibatkan hubungan antara stimulus dan respon. Namun belajar mengharuskan terjadinya proses berpikir yang sangat kompleks. Lebih jauh dalam teori ini dikatakan bahwa ilmu pengetahuan dibangun dalam diri seseorang individu melalui proses interaksi yang berkesinambungan dengan lingkungan.

Teori konstruktivisme dikembangkan oleh Vygotsky (Sri Utami Halman, 2012) yang menyimpulkan bahwa peserta didik mengkonstruksikan pengetahuan atau menciptakan makna sebagai hasil dari pemikiran dan berinteraksi dalam suatu konteks sosial. Teori ini sejalan dengan pemikiran Piaget yang menyatakan bahwa setiap individu menciptakan makna dan pengertian baru berdasarkan interaksi antara apa yang telah dimiliki, diketahui, dipercayai, dengan fenomena, ide, atau informasi baru yang dipelajari. Dengan demikian, dalam proses belajar mahasiswa telah membawa pengertian dan pengetahuan awal yang harus ditambah, dimodifikasi, diperbaharui, direvisi, dan diubah oleh informasi baru yang didapat dalam proses belajar.

Selanjutnya Vygotsky (Sri Utami Halman,2012) menyatakan bahwa proses belajar tidak dapat dipisahkan dari aktivitas dan interaksi, karena persepsi dan aktivitas berjalan seiring secara dialogis. Pengetahuan tidak dipisahkan dari aktivitas di mana pengetahuan itu dikonstruksikan, dan di mana makna 
Keefektifan Model Pembelajaran Berbasis Budaya (PBB) untuk Meningkatkan Hasil Belajar IPS (Firosalia Kristin)

diciptakan, serta dari komunitas budaya di mana pengetahuan didesiminasikan dan diterapkan. Kerangka pemikiran konstruktivisme menantang tenaga pengajar dan perancang pembelajaran untuk mampu menciptakan, mengkreasikan lingkungan belajar yang memungkinkan tenaga pengajar dan siswa berpartisipasi aktif dalam proses berpikir, mencari, menemukan, dan menciptakan makna berdasarkan pengalaman dan pengetahuan awal yang dimiliki tenaga pengajar maupun siswa dalam suatu komunitas budaya, sehingga dapat dicapai pemahaman terpadu.

\section{SIMPULAN}

Berdasarkan hasil penelitian yang telah diperoleh dengan analisis data dan pengujian hipotesis, maka dapat ditarik kesimpulan bahwa model Pembelajaran Berbasis Budaya (PBB) lebih efektif dibandingkan model konvensional untuk meningkatkan hasil belajar IPS siswa kelas IV SD Negeri 01 Tridarma Wirajaya Lampung. Hasil penelitian menunjukkan bahwa nilai hasil uji-t diperoleh nilai

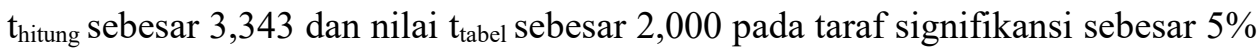
$(0,05)$. Di samping itu, model PBB dapat meningkatkan aktivitas belajar siswa pada lima aspek yaitu antusiasme, keaktifan, tanggung jawab, kepercayaan diri dan diskusi, bahwa dari ke lima aspek tersebut dari pertemuan pertama sampai pertemuan ke enam mengalami kenaikan yang signifikan.

Berdasarkan hasil penelitian dan keterbatasan-keterbatasan dalam penelitian ini, maka dapat diajukan saran sebagai berikut:

1) Untuk meningkatkan hasil belajar IPS pada siswa, guru dapat menggunakan model PBB, karena model ini terbukti efektif dalam meningkatkan hasil belajar IPS, seperti yang dilakukan dalam penelitian ini.

2) Dalam melaksanakan pembelajaran dengan $\mathrm{PBB}$, guru harus benar-benar mempersiapkan diri dan menguasai materi yang akan disampaikan. Selain itu perlunya motivasi yang optimal dalam upaya meningkatkan antusiasme, keaktifan, tanggung jawab dan kepercayaan diri siswa dalam mengikuti pembelajaran di kelas.

3) Hasil penelitian ini dapat dijadikan dasar penelitian lanjutan dengan menghubungkan variabel penelitian dengan variabel lain, dan memperdalam kajian tentang model PBB dalam upaya meningkatkan hasil belajar siswa dalam mata pelajaran IPS.

4) Penerapan model PBB dalam pembelajaran IPS, peneliti lanjutan juga dapat melakukan penelitian tentang aktivitas mengajar guru selama mengajar di kelas. 


\section{DAFTAR PUSTAKA}

Akto Gunawan. 2012. Pembelajaran berbasis budaya. Diambil pada 27 September 2012, dari: http://www.scribd.com/doc/87693943/ PEMBELAJARAN-BERBASIS-BUDAYA.

Alexon. 2010. Pembelajaran terpadu berbasis budaya. Bengkulu: FKIP UNIB Press.

Burhan Nurgiantoro, Gunawan dan Marzuki. 2004. Statistik terapan. Yogyakarta: Gadjah mada University Press

Irawan Sadad Sadiman dan Shendy Amalia. 2008. Ilmu pengetahuan sosial untuk SD/MI kelas IV. Jakarta: Pusat Perbukuan Depdikas.

Mulyono Abdurrahman. 2003. Pendidikan bagi anak berkesulitan belajar. Jakarta: Rineka Cipta.

Nana Sudjana. 2002. Dasar-dasar proses belajar dan mengajar. Bandung: Sinar Baru Algensindo.

Paul Suparno. 2012. Teori perkembangan kognitif jean Piaget. Yogyakarta Kanisius.

Santrock, J.W. 2004. Life span development (9th ed.). New York: McGraw Hill.

Saliman. 2007. Penerapan pembelajaran berbasis budaya sebagai upaya peningkatan kualitas pembelajaran pada mata kulia perencanaan pembelajaran. Jurnal Penelitian. Yogyakarta: UNY.

Sri Utami Halman. 2012. Teori perkembangan kognitif Vygotsky dan Piaget. Diambil dari: http://utamitamii.blogspot.com/2012/04/teori-perkembangan kognitif-vygotsky.htmlDiakses tanggal 27 Oktober 2012.

Suharsimi Arikunto. (2007). Manajemen Penelitian. Jakarta: Bumi Aksara.

Sutarno. 2012. Pembelajaran berbasis budaya. Diambil dari: http://pjjpgsd. dikti.go.id/file.php/1/repository/dikti/Mata\%20Kuliah\%20Awal/Pen didikan\%20Multikultural/BAC/Multikultural_UNIT\%2B7_Coverbe lakang.pdf. Diakses tanggal 3 November $201 \overline{2}$. 